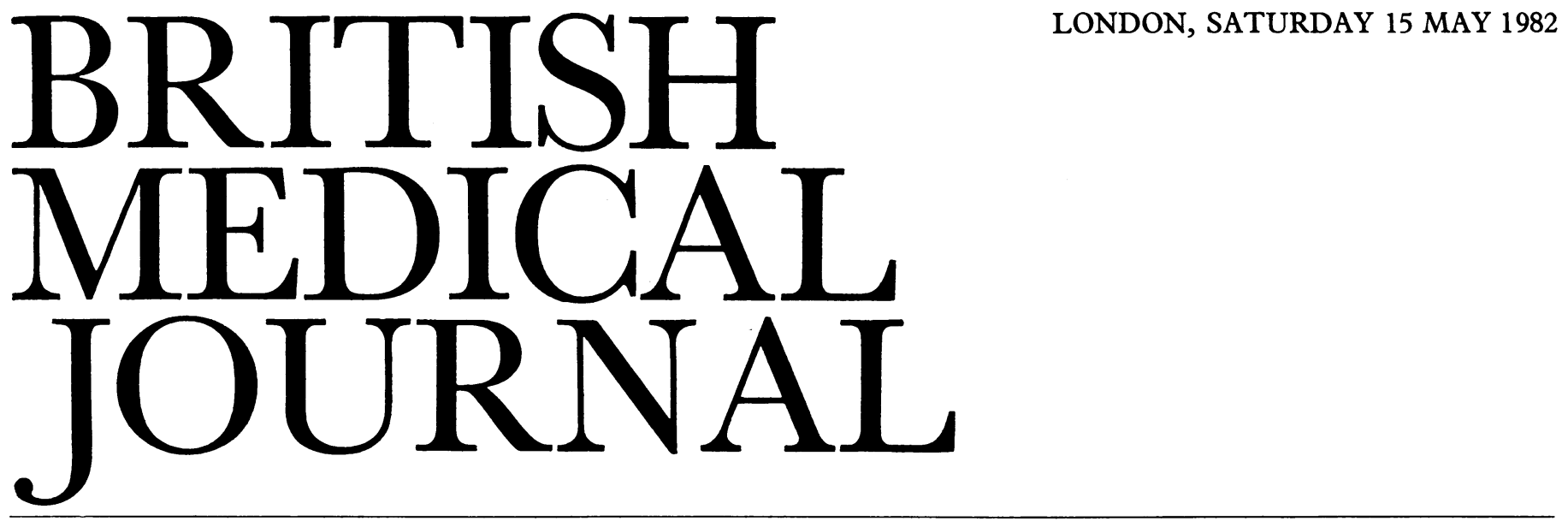

\title{
The female carrier of Duchenne muscular dystrophy
}

Duchenne muscular dystrophy is an X-linked recessive disorder, affecting only males and transmitted by females, who have a $50 \%$ risk of an affected son or a carrier daughter. The incidence has been estimated at between one in 3000 and one in 5000 male births, ${ }^{1}$ but not all the mothers of affected infants are carriers; a substantial proportion of cases will represent new mutations. According to Haldane, ${ }^{2}$ the mutation rate for a potentially lethal $\mathrm{X}$-linked condition in which the biological fitness (fertility) of affected males is practically zero would be one-third. Estimates based on population studies have produced a similarly high figure. ${ }^{3-5}$

If, then, one-third of the mothers of affected infants are not carriers the investigation of the carrier state and genetic counselling are vitally important for the families concerned. The first essential step in genetic counselling must always be to verify the diagnosis in the index case. Next, a detailed family tree should be constructed before investigation of the possible carrier is begun. A genetically definite or obligate carrier is a woman with an affected son and an additional affected male relative; all other female relatives are possible carriers.

The creatine kinase test is the most reliable for detecting carriers. The serum activity of the enzyme is grossly raised in patients with Duchenne dystrophy, and raised to a mild-tomoderate extent in some but not all female carriers of the gene. ${ }^{6}$ Several studies have shown the proportion of genetically obligate carriers with definitely raised creatine kinase activities to be about two-thirds. ${ }^{7-9}$ Since creatine kinase activity is normal in about a third of definite carriers it clearly does not exclude the carrier state. An accurate estimate of the statistical risk that a woman with a normal creatine kinase activity is a carrier can be made from the actual activity of the creatine kinase, on the basis of the distribution curves in normal controls and in obligate carriers and the application of Bayesian theory, which takes account both of the antecedent family history and of the creatine kinase activity of the person at risk and of other female relatives. ${ }^{10}$ Follow-up studies of families counselled in this way have verified the validity of this approach. ${ }^{11-13}$ The creatine kinase activity can be spuriously high after vigorous exercise and it drops during pregnancy. ${ }^{14} 15$ Genetic counselling requires the combined skills of the physician and the laboratory and is best undertaken in specialised centres; random counselling based on isolated results of estimation of creatine kinase can have disastrous consequences. ${ }^{16}$

Other biochemical tests have been tried in the detection of carriers. Some, such as that based on raised serum activity of pyruvate kinase, are at least potentially practicable, ${ }^{17-19}$ though having little or no advantage over creatine kinase. ${ }^{20-22}$ Others, such as the tests based on abnormal polyribosomal protein synthesis of muscle in vitro, ${ }^{23}$ changes in phosphorylation of erythrocyte membrane spectrin $\mathrm{II},{ }^{24}$ increased lactate dehydrogenase isoenzyme $5,{ }^{25}$ and reduction in lymphocyte capping, ${ }^{26}$ are much more complex and still need validation. Electrocardiographic abnormalities, ${ }^{8}{ }^{27}$ changes on quantitative electromyography, ${ }^{28-30}$ and pathological changes in the muscle under light ${ }^{31} 32$ or electron microscopy ${ }^{33}{ }^{34}$ have also been used as supplementary tests for detecting carriers; and some authors have favoured combined tests. ${ }^{34-37}$

All these methods detect only some carriers; but an abnormality on one test, such as abnormal histological appearances of muscle, may occur with normal activities of creatine kinase and vice versa. ${ }^{34}{ }^{38}$ Careful quantification of histochemical and histological features on needle biopsy in obligate carriers and volunteer controls has helped to standardise the methods and to identify significant deviation in fibre size, fibre type, and internal nuclei. ${ }^{38}$

On clinical examination several features may be found in carriers, ranging from prominence of the calves (often unilateral) through muscle cramps or minimal weakness to overt muscle wasting and weakness. Moser and Emery ${ }^{39}$ estimated that about $8 \%$ of female carriers have symptoms. Roses et $a l^{25}$ detected muscle weakness in a very high proportion of female relatives but as their findings were based on subjective manual testing more objective quantitative estimates of muscle force in definite carriers and normal controls are needed to validate (or refute) this claim.

The striking variability of all abnormalities in carriers can be explained on the Lyon hypothesis ${ }^{40}$ of random inactivation in each cell of one $\mathrm{X}$ chromosome, which can be either the paternal (normal) or maternal (abnormal) X chromosome. This would also explain the discordance of creatine kinase 
activity and histological features ${ }^{31}$ or of clinical weakness ${ }^{41}$ in monozygotic twin carriers.

The overtly weak heterozygote with the Duchenne gene may on rare occasions manifest the actual disease owing to a concomitant chromosomal abnormality such as (presumptive) Turner's syndrome (XO), ${ }^{42} \mathrm{XO} / \mathrm{XX}$ mosaicism, ${ }^{43}{ }^{44}$ a structurally abnormal $\mathrm{X}$ chromosome, ${ }^{45}$ or a translocation with partial deletion of the $\mathrm{X}$ chromosome. ${ }^{46}$ Such women must also be distinguished from those with autosomal recessive limb girdle dystrophy. ${ }^{10} \mathrm{~A}$ further three carriers of Duchenne muscular dystrophy with overt clinical weakness, high creatine kinase activities, electrocardiographic abnormalities, and histological changes have recently been reported from Japan. ${ }^{47}$ Only one was a genetically definite carrier (with two affected sons and an affected brother); the other two were mothers of isolated cases.

Accurate diagnosis of the non-carrier state in the female at risk, such as the sister of an affected boy, continues to present a difficult clinical problem. At present the best that can be offered is a statistical estimate based on accurate laboratory and associated data. Further tests based on secondary manifestations of the gene are unlikely to help to identify all carriers more accurately. For this we may have to await discovery of the basic biochemical abnormality, unless the application of recent advances in recombinant DNA technology 4849 provides a reliable marker for Duchenne dystrophy. Hopefully, diagnosis on the basis of the defect in DNA would accurately diagnose all cases, both prenatally and postnatally, as well as all carriers of the gene, even before the fundamental abnormality became clinically apparent.

VICTOR Dubowitz

Professor of Paediatrics,

Hammersmith Hospital,

London W12 0HS

${ }^{1}$ Emery AEH. Genetic considerations in the X-linked muscular dystrophies. In: Rowland LP, ed. Pathogenesis of human muscular dystrophies. Amsterdam: Excerpta Medica, 1977:42-52. (International Congress Series, No 404.)

2 Haldane JBS. Rate of spontaneous mutation of human gene. Fournal of Genetics $1935 ; 31: 317-26$.

${ }^{3}$ Gardner-Medwin D. Mutation rate in Duchenne type of muscular dystrophy. 7 Med Genet 1970;7:334-7.

4 Davie AM, Emery AE. Estimation of proportion of new mutants among cases of Duchenne muscular dystrophy. F Med Genet 1978;15:339-45.

5 Conlon T. The proportion of carriers in DMD: a comparison of biochemical and pedigree methods. In: Kidman AD, Tomkins JK, Westerman RA, eds. New approaches to nerve and muscle disorders: basic and applied contributions. Amsterdam: Excerpta Medica, 1981: 345-50. (International Congress Series, No 546.)

${ }^{6}$ Dreyfus JC, Schapira G, Demos J. Study of serum creatine kinase in myopathic patients and their families. Revue Française d'Etudes Cliniques et Biologiques 1960;5:384-6.

${ }^{7}$ Hausmanowa-Petrusewicz I, Prot J, Niebrój-Dobosz I, et al. Studies of healthy relatives of patients with Duchenne muscular dystrophy. f Neurol Sci $1968 ; 7: 465-80$.

${ }^{8}$ Emery AE. Genetic counselling in X-linked muscular dystrophy. 7 Neurol Sci 1969;8:579-87.

- Gardner-Medwin D, Pennington RJ, Walton JN. The detection of carriers of X-linked muscular dystrophy genes. A review of some methods studied in Newcastle upon Tyne. $\mathcal{F}$ Neurol Sci $1971 ; 13: 459-74$.

10 Emery AEH. Duchenne muscular dystrophy: genetic aspects, carrier detection and antenatal diagnosis. Br Med Bull 1980;36:117-22.

11 Emery AE, Watt MS, Clack ER. The effects of genetic counselling in Duchenne muscular dystrophy. Clin Genet $1972 ; 3: 147-50$.

12 Dennis NR, Evans K, Clayton B, Carter CO. Use of creatine kinase for detecting severe $\mathrm{X}$-linked muscular dystrophy carriers. $\mathrm{Br} \mathrm{Med} \mathfrak{f}$ 1976 ;ii:577-9.

${ }^{13}$ Hutton EM, Thompson MW. Carrier detection and genetic counselling in Duchenne muscular dystrophy: a follow-up study. Can Med Assoc $\mathcal{F}$ $1976 ; 115: 749-52$.

14 Blyth H, Hughes BP. Pregnancy and serum-CPK levels in potential carriers of "severe" X-linked muscular dystrophy. Lancet 1971 ;i :855-6.

${ }^{15}$ King B, Spikesman A, Emery AE. The effect of pregnancy on serum levels of creatine kinase. Clin Chim Acta 1972;36:267-9.
${ }^{16}$ Dubowitz V. Genetic miscounselling in muscular dystrophy. Arch Dis Child 1976;51:325.

17 Alberts MC, Samaha FJ. Serum pyruvate kinase in muscle disease and carrier states. Neurology (Minneap) 1974 ;24:462-4.

18 Percy ME, Chang LS, Murphy EG, Oss I, Verellen-Dumoulin C, Thompson MW. Serum creatine kinase and pyruvate kinase in Duchenne muscular dystrophy carrier detection. Muscle Nerve 1979;3:329-39.

19 Sage J, Inati Y, Samaha F. The importance of serum pyruvate kinase in neuromuscular diseases and carrier states. Muscle Nerve 1979;2.390-3.

${ }^{20}$ Seay AR, Ziter FA, Wu LH, Wu JT. Serum creatine phosphokinase and pyruvate kinase in neuromuscular disorders and Duchenne dystrophy carriers. Neurology (Minneap) 1978;28:1047-50.

${ }^{21}$ Hardy MF, Gardner-Medwin D, Pennington RJ. Serum pyruvate kinase in carriers of Duchenne muscular dystrophy. $\mathcal{F}$ Neurol Sci 1977;32: 137-9.

22 Yamuna S, Valmikinathan K, Burt D, et al. Serum pyruvate kinase in carriers of Duchenne muscular dystrophy. Clin Chim Acta 1977;79: 277-9.

${ }^{23}$ Ionasescu V, Zellweger $\mathrm{H}$, Shirk $\mathrm{P}$, et al. Identification of carriers of Duchenne muscular dystrophy by muscle protein synthesis. Neurology (Minneap) $1973 ; 23: 497-502$.

24 Roses AD, Roses MJ, Miller SE, Kull KL, Appel SH. Carrier detection in Duchenne muscular dystrophy. N Engl f Med 1976;294:193-8.

${ }^{25}$ Roses MS, Nicholson MT, Kircher CS, Roses AD. Evaluation and detection of Duchenne's and Becker's muscular dystrophy carriers by manual muscle testing. Neurology (Minneap) 1977;27:20-5.

${ }^{26}$ Pickard NA, Gruemer H-D. Lymphocyte capping in Duchenne muscular dystrophy. N Engl F Med 1979;300:861-2.

27 Lane RJ, Gardner-Medwin D, Roses AD. Electrocardiographic abnormalities in carriers of Duchenne muscular dystrophy. Neurology (NY) $1980 ; 30: 497-501$.

${ }^{28}$ Gardner-Medwin D. Studies of the carrier state in the Duchenne type muscular dystrophy. 2. Quantitative electromyography as a method of carrier detection. F Neurol Neurosurg Psychiatry 1968;31:124-34.

${ }^{29}$ Moosa A, Brown BH, Dubowitz V. Quantitative electromyography: carrier detection in Duchenne type muscular dystrophy using a new automatic technique. $\mathcal{F}$ Neurol Neurosurg Psychiatry 1972;35:841-4.

${ }^{30}$ Valli G, Scarlato G, Contartese $M$. Quantitative electromyography in the detection of the carriers in Duchenne type muscular dystrophy. f Neurol 1976;212:139-49.

31 Dubowitz V. Myopathic changes in muscular dystrophy carriers. Proc $R$ Soc Med 1963;56:810-2.

${ }^{32}$ Emery AEH. Clinical manifestations in two carriers of Duchenne muscular dystrophy. Lancet $1963 ; \mathrm{i}: 1126-8$.

${ }^{33}$ Milhorat AT, Shafiq SA, Goldstone L. Changes in muscle structure in dystrophic patients, carriers and normal siblings seen by electron microscopy; correlation with levels of serum creatinephosphokinase (CPK). Ann NY Acad Sci 1966;138:246-92.

${ }^{34}$ Roy S, Dubowitz V. Carrier detection in Duchenne muscular dystrophy. A comparative study of electron microscopy, light microscopy and serum enzymes. $\mathcal{f}$ Neurol Sci 1970;11:65-79.

35 Hausmanowa-Petrusewicz I, Prot J, Dobosz I, et al. Further studies concerning the detection of carriership in the Duchenne type of dystrophy. Eur Neurol 1971;5:186-96.

${ }^{36}$ Hausmanowa-Petrusewicz I, Niebroj-Dobosz I, Borkowska J, Lukasik E, Liszewska-Pfejfer D. Carrier detection in Duchenne dystrophy. In: Rowland LP, ed. Pathogenesis of human muscular dystrophies. Amsterdam: Excerpta Medica, 1977:32-41. (International Congress Series, No 404.)

${ }^{37}$ Radu H, Migea S, Török A, Bordeianu L, Radu A. Carrier detection in $\mathrm{X}$-linked Duchenne type muscular dystrophy. A pluridimensional investigation. 7 Neurol Sci 1968;6:289-300.

${ }^{38}$ Maunder-Sewry CA, Dubowitz V. Needle muscle biopsy for carrie detection in Duchenne muscular dystrophy. I. Light microscopy: histology, histochemistry and quantitation. F Neurol Sci 1981 ;49:305-24.

${ }^{39}$ Moser H, Emery AE. The manifesting carrier in Duchenne muscula dystrophy. Clin Genet $1974 ; 5: 271-84$.

40 Lyon MF. Sex chromatin and gene action in the mammalian X-chromosome. Am f Hum Genet 1962;14:135-48.

41 Gomez MR, Engel AG, Dewald G, Peterson HA. Failure of inactivation of Duchenne dystrophy X-chromosome in one of female identical twins. Neurology (Minneap) 1977;27:537-41.

42 Walton JN. On inheritance of muscular dystrophy. Ann Hum Genet $1955 ; 21: 1-38$

${ }^{43}$ Ferrier P, Bamatter F, Klein D. Muscular dystrophy (Duchenne) in a girl with Turner's syndrome. F Med Genet 1965;2:38-46.

44 Jalbert P, Mouriquand D, Beaudoing A, Jaillard M. Myopathie progressive de type Duchenne et mosaique $\mathrm{XO} / \mathrm{XX} / \mathrm{XXX}$ : considerations sur la génese de la fibre muscular striée. Ann Genet (Paris) 1966;9:104-8.

45 Berg BO, Conte F. Duchenne muscular dystrophy in a female with structurally abnormal X-chromosome. Neurology (Minneap) 1974;24: 356

${ }^{46}$ Lindenbaum RH, Clarke G, Patel C, Moncrieff M, Hughes JT. Muscular dystrophy in an $\mathrm{X} ; 1$ translocation female suggests that Duchenne locus is on X chromosome short arm. F Med Genet 1979;16:389-92.

47 Yoshioka $M$. Clinically manifesting carriers in Duchenne muscular dystrophy. Clin Genet $1981 ; 20: 6-12$.

${ }^{48}$ Robinson L. Split genes and muscular dystrophy. Muscle Nerve 1979 ;2: 258-64.

49 Emery AEH. Recombinant DNA tcchnology. L.ancet 1981 ;ii:1406-9. 